\title{
High sweat electrolytes in a malnourished child
}

\author{
E A Jasinge, D A N P Meeriyagalle \\ Department of Chemical Pathology, Lady Ridgeway Hospital, Colombo
}

\begin{abstract}
This case report describes an infant who presented with loose stools and none resolving respiratory tract infection and was found to have high sweat electrolyte levels. The sweat electrolyte concentrations declined during the course of treatment. This case report highlights the need to be aware of the false positive sweat test results that can occur in malnutrition and describes the important points in carrying out a proper sweat test.

Keywords: sweat test, malnutrition, cystic fibrosis.
\end{abstract}

\section{Introduction}

The sweat test is a quantitative measurement of sweat chloride and sodium and is a key investigation in the diagnosis of cystic fibrosis (CF). ${ }^{1}$ Hence it is carried out in our hospital in patients who present with recurrent respiratory tract infections and chronic diarrhea to find out a cause when the other investigations do not help. A sweat chloride concentration of $>60$ $\mathrm{mmol} / \mathrm{L}$, strongly supports the diagnosis of CF. There are a number of other conditions, including malnutrition, which can cause an elevated sweat chloride concentration.

\section{Case Report}

A four-month-old boy was admitted to the Lady Ridgeway Hospital with a history of loose stools, respiratory tract infection of one month duration and generalized body rash of two weeks duration. The child was born by normal vaginal delivery at term to non-consanguineous parents. His birth weight was $2.9 \mathrm{~kg}$. Since birth the child had developed well till 3 months of age. On examination, this $4.1 \mathrm{~kg}$ child was found to be pale, irritable and ill-looking. Flaky paint dermatitis was found over hands, back of the trunk and legs. Examination of the respiratory system revealed the bilateral crackles in the bases. An enlarged liver, $3 \mathrm{~cm}$ below the costal margin was found. The problems encountered in this patient were failure to thrive, 'flaky paint' dermatitis, non resolving respiratory tract infection and passage of mucoid stools.

Address for correspondence: E.A. Jasinge, Department of Chemical Pathology, Lady Ridgway Hospital, Colombo 8, Sri Lanka.

e-mail: munidasa@cga.Ik 
The results of the basic investigations are listed in the table 1 . Stool culture and ABST was negative for salmonella, shigella and campylobacter. Stool full report showed numerous fat globules and no reducing substances. Ultrasound scan of the abdomen showed hepatomegaly with fatty infiltration. The results of sweat test performed along with serum protein on similar days are listed in table 2 . The child was managed with intravenous antibiotics for the respiratory tract infection. Supplements of iron, folic acid, vitamin A, vitamin B and zinc were given. He was initially fed with soya based formulae. This was changed to breast milk and weaning. Several doses of intravenous $5 \%$ albumin were also administered.

Within two weeks of admission the diarrhea settled and the flaky paint dermatitis disappeared within one week. The diagnosis was given as kwashiorkor due to chronic diarrhea.

Table 1. Laboratory investigations

\begin{tabular}{|cc|cc|}
\hline Test & Value & Test & Value (normal range) \\
\hline Haemoglobin & $9.7 \mathrm{~g} / \mathrm{dL}$ & SGOT & $47 \mathrm{U} / \mathrm{L}(9-48)$ \\
\hline $\mathrm{MCV}$ & $70 \mathrm{fL}$ & SGPT & $24 \mathrm{U} / \mathrm{L}(10-40)$ \\
\hline $\mathrm{MCH}$ & $26.4 \mathrm{pg}$ & Total Protein & $42 \mathrm{~g} / \mathrm{L}(54-88)$ \\
\hline $\mathrm{MCHC}$ & $37.8 \mathrm{~g} / \mathrm{dL}$ & Albumin & $21 \mathrm{~g} / \mathrm{L}(34-50)$ \\
\hline Platelet & $275,000 \mathrm{~mm}^{3}$ & Corrected Ca & $2.5 \mathrm{mmol} / \mathrm{L}(2.2-2.7)$ \\
\hline WBC & $19,800 \mathrm{~mm}^{3}$ & Magnesium & $0.97 \mathrm{mmol} / \mathrm{L}(0.66-1.04)$ \\
\hline Neutrophils & $60 \%$ & TSH & $5.3 \mathrm{IU} / \mathrm{L}(0.7-.5 .7)$ \\
\hline Blood picture & $\begin{array}{c}\text { Evidence of } \\
\text { infection }\end{array}$ & HIV screening & negative \\
& \multicolumn{2}{|c}{} & \\
\hline
\end{tabular}

Table 2. The results of the sweat test and serum proteins

\begin{tabular}{|ccccc|}
\hline $\begin{array}{c}\text { Day from } \\
\text { admission }\end{array}$ & $\begin{array}{c}\text { Sweat sodium } \\
(\mathrm{mmol} / \mathrm{L})(<40)\end{array}$ & $\begin{array}{c}\text { Sweat chloride } \\
(\mathrm{mmol} / \mathrm{L})(<40)\end{array}$ & $\begin{array}{c}\text { Total protein }(\mathrm{g} / \mathrm{L}) \\
(54-88)\end{array}$ & $\begin{array}{c}\text { Albumin }(\mathrm{g} / \mathrm{L}) \\
(34-50)\end{array}$ \\
\hline Day 7 & 113.4 & 128.5 & 42 & 25 \\
\hline Day 12 & 105 & 98 & - & - \\
\hline Day 15 & 72.1 & 95.5 & - & 31.6 \\
\hline Day 25 & 48 & 62 & 56.8 & \\
\hline
\end{tabular}




\section{Discussion}

Cystic Fibrosis (CF) is an autosomal recessive disease resulting from mutations in the cystic fibrosis trans-membrane conductance regulator (CFTR) gene on chromosome $7 .^{2}$

The sweat test, a quantitative measurement of chloride and sodium remains an important laboratory test to support the diagnosis of CF. Since CF is a serious disease, false positive and false negative sweat test results can have detrimental consequences. There are a variety of disorders in addition to CF that can cause elevations in sweat electrolyte concentrations (Table 3). 3,4 Most of these disorders are distinguishable from CF on the basis of clinical presentation. It is of utmost clinical importance that the sweat test be carried out accurately to minimize contamination. ${ }^{5}$ Poor performance of sweat test analysis can lead to misdiagnosis. Sweat collection must be performed by fully trained and experienced personnel. Sweat analysis should be performed by qualified and experienced laboratory technologists. ${ }^{1}$

Table 3. Diseases other than CF associated with an elevated sweat electrolyte concentration

\begin{tabular}{|l|l|}
\hline Anorexia nervosa & Mucopolysaccharidoses type-1 \\
Atopic dermatitis & Nephrogenic diabetes insipidus \\
Glucose-6-phosphate dehydrogenase deficiency & Protein calorie malnutrition \\
Glycogen storage disease type-1 & Untreated adrenal insufficiency \\
Hypogammaglobulinaemia & Untreated hypothyroidism \\
\hline
\end{tabular}

The laboratory must be one which performs sweat tests on a regular basis to maintain expertise. ${ }^{5}$ False high sweat results can occur if the skin of the patient is not cleaned properly or if contaminated filter papers are used. A blank determination should be carried out to assure that filter papers are low in sodium and chloride content . ${ }^{4}$ Great care should be taken to prevent evaporation. ${ }^{1,5}$ Hence sweat is collected only for $30 \mathrm{~min}$ in our laboratory. The measurement of sweat chloride and not the sodium concentration is the definitive test for diagnosis. ${ }^{1,5}$ Chloride concentration $>60 \mathrm{mmol} / \mathrm{L}$ is strongly suggestive of $\mathrm{CF}^{5}$. The sweat chloride can be measured by colorimetry (titrimetric or spectro photometric), coulometry (chloridometer) or ion-selective electrode technique. ${ }^{5}$

Sweat sodium concentration may also be measured as a check on the chloride result, since there is little difference between sodium and chloride concentration in the sweat. For quality control purposes a significant discordance between the two electrolyte concentrations (>20 $\mathrm{mmol} / \mathrm{L}$ ) can indicate technical error in collection, analysis, or both. ${ }^{3,5}$ We analyze aqueous electrolyte solutions such as N/2 and N/5 saline as internal quality controls in our laboratory with the patient's samples. Sodium can be measured by flame photometry, atomic absorption spectrophotometry and ion selective electrode technique. ${ }^{5}$ Sodium concentration must not be 
measured alone. ${ }^{1,5}$ In our laboratory we measure both sodium and chloride by ion-selective electrode technique.

The sweat test was performed on this patient once his skin lesions were healed, as this patient had some of the features of cystic fibrosis. Though his first sweat test results are in favor of CF with a sweat chloride concentration of $>60 \mathrm{mmol} / \mathrm{L}$, he also had severe protein energy malnutrition due to chronic diarrheoa which was evident by serum protein results. With treatment of malnutrition, repeated sweat test results declined. This confirms the fact that the abnormal sweat test in this patient was due to protein-calorie malnutrition and not due to CF, where repeated sweat test results should remain high.

\section{Acknowledgements}

We are thankful to Dr Sarath Silva, Consultant Paediatrician and Dr. Sri Saravanan Pawanthan, Registrar ward 3, Lady Ridgeway hospital, who managed the patient and the laboratory staff in the department of chemical pathology for their immense technical assistance.

\section{References}

1. Green A, Kirk J. Guidelines for the performance of the sweat test for the diagnosis of cystic fibrosis. Ann Clin Biochem. 2007; 44: 25-34.

2. Knowles MR, Durie PR. What is cystic fibrosis? N Engl J Med. 2002; 347: 39-42.

3. LeGrys VA. Sweat testing for the diagnosis of cystic fibrosis: practical considerations. The Journal of Pediatrics. 1996; 129(06): 892-7.

4. Scott MG, Heusel JW, LeGrys VA et al. Electrolytes and Blood Gases. In: Burtis C.A, Ashwood E.R editors. Tietz Textbook of Clinical chemistry. $3^{\text {rd }}$ ed. Philadelphia: W. B. Saunders; 1999. 1056-92.

5. Australian guidelines for the performance of the sweat test for the diagnosis of cystic fibrosis; report from the AACB sweat testing working party. Clin Biochem Rev. May 2006; 27(Suppl 1). 